\title{
ДИНАМІКА ІНТЕРЛЕЙКІНІВ У ХВОРИХ НА ЛАЙМ-БОРЕЛІОЗ
}

Вступ. Лайм-бореліоз (ЛБ) - трансмісивний природно-осередковий бактеріоз, спричинений патогенними бореліями, передається кліщами роду Iхоdes, характеризується поліморфрізмом клінічної симптоматики. Фактори вірулентності B. burgdorferi - поверхневі Osp-білки активують макрофраги, дендритні клітини, Т- і В-лімфоцити, що виділяють такі особливі речовини білкової природи, як цитокіни. Останні виконують медіаторну фрункцію, передаючи сигнали між клітинами, що взаємодіють. Вивчення динаміки активності прозапальних іпротизапальних цитокінів дозволяє з'ясувати нові ланки імунопатогенезу борелійної інорекції.

Мета дослідження - з'ясувати динаміку прозапальних цитокінів ІЛ-1 $\beta$, ФНП- $\alpha$, ІЛ-6 і протизапального ІЛ-10 у сироватці крові пацієнтів з еритемною фрормою Лайм-бореліозу залежно від перебігу хвороби.

Методи дослідження. Спостерігали 83 особи віком від 18 до 70 років з еритемною формою Лайм-

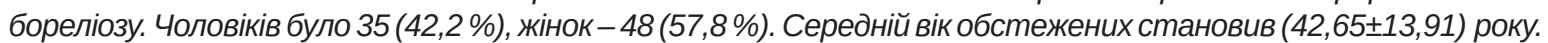
Пацієнтів поділили на три групи: 1-шу становили 38 (45,7 \%) осіб з гострим перебігом ЛБ (до 3-х місяців); 2-гу - 32 (38,6 \%) пацієнти з підгострим перебігом (від 3-х до 6-ти місяців); 3-тю - 13 (15,7 \%) хворих із хронічним перебігом недуги (понад 6 місяців). Антитіла до B. burgdorferi s. I. Ig M ma/aбо Ig G визначали методом ІФА, рівень цитокінів (ФНП- $\alpha$, ІЛ-1 $\beta$, ІЛ-6 та ІЛ-10) у сироватці крові пацієнтів - методом ІФА із застосуванням тест-систем виробництва ЗАТ "Вектор-Бест".

Результати й обговорення. При гострому перебігу ЛБ у сироватці крові хворих зростав вміст прозапальних ІЛ-1 $\beta$, ФНП- $\alpha$ та ІЛ-6 порівняно з контрольною групою ( $p<0,005)$, збільшувався вміст протизапального ІЛ-10 щодо рівня у здорових осіб $(p<0,005)$. При підгострому перебігу ЛБ вміст прозапального ІЛ-1ß не змінювався, а концентрація ФНП- $\alpha$ була вищою, ніж при гострому перебігу недуги $(p<0,05)$ і в контрольній групі (p<0,005). Рівень протизапального ІЛ-10 у цих осіб був нижчим, ніж у пацієнтів з гострим перебігом ЛБ ( $p>0,05)$, проте значно вищим за показник у здорових людей ( $p<0,005)$. В осіб, в яких кільцеподібна мігруюча еритема визначалася через 6 місяців і більше, вміст ІЛ-1 $\beta$ не зростав, рівень ФНП- $\alpha$ був дещо вищим, ніж у пацієнтів з гострим перебігом недуги (p>0,05), а концентрація ІЛ-6 виявилась значно вищою щодо осіб з підгострим перебігом недуги, суттєво не відрізняючись від показника у хворих з гострим ЛБ.

Висновки. Кожний п'ятий пацієнт з кільцеподібною мігруючою еритемою не зміг вказати на укус кліща. Збільшений рівень ІЛ-10 у сироватці крові пацієнтів з ЛБ на тлі високого вмісту прозапальних цитокінів може свідчити про відсутність передумов для переходу інфрекційного процесу в стадію обмеження запалення даної інфрекції і бути, ймовірно, показанням до негайного призначення етіотропного лікування або заміни одного антибіотика іншим.

КЛЮчОВІ СЛОВА: Лайм-бореліоз; прозапальні цитокіни; протизапальний інтерлейкін; перебіг хвороби.

ВСТУП. Іксодовий кліщовий бореліоз трансмісивний природно-осередковий бактеріоз, спричинений патогенними бореліями, який передається кліщами роду Ixodes, характеризується поліморфрізмом клінічної симптоматики, переважним ураженням шкіри, серцево-судинної та нервової систем, опорно-рухового апарату, схильністю до хронічного і рецидивного перебігу [1].

(c) М. І. Шкільна, М. А. Андрейчин, О. Л. Івахів, Я. І. Йосик, Н. Г. Завіднюк, М. С. Творко, М. М. Корда, І. М. Кліщ, 2020
Патогенез борелійної інфекції зумовлений, з одного боку, патогенною дією збудника, а 3 іншого - характером імунної відповіді макроорганізму [2, 3]. Фактори вірулентності B. burgdorferi поверхневі Osp-білки (ліпопротеїни зовнішньої мембрани збудника) $[4,5]$ активують макрофраги, дендритні клітини, Т-іВ-лімфоцити, що виділяють такі особливі речовини білкової природи, як цитокіни $[6,7]$. Цитокіни - високоспецисрічні регуляторні пептиди, що продукують клітини 
імунної системи, а також органів і систем, залучених у запальний процес. Вони виконують медіаторну фрункцію, передаючи сигнали між клітинами, що взаємодіють [3].

Цитокіни першої хвилі - інтерлейкін (ІЛ) 1 i фрактор некрозу пухлини $\alpha$ (ФНП- $\alpha)$, який є потужним індуктором прозапальних цитокінів, зокрема ІЛ-1及, ІЛ-6 та ІЛ-8 [8]. Цитокіни родини ІЛ-1 спричинюють запалення і здійснюють регуляцію відповіді Т-лімфроцитів, запускаючи проліферацію преактивованих антигеном Т- і В-лімфоцитів. Водночас, залежно від особливостей антигену, відбувається диореренціація Т-хелперів у клітини 1-го чи 2-го типу: Th1 i Th2. Активація Th1-клітин, які секретують ІЛ-2, інтерфрерон-у (ІФН-у) і ФНП- $\alpha$, зумовлює стимуляцію функцій Т-лімфроцитів і макрофрагів, а також розвиток клітинного типу імунної відповіді. У свою чергу, синтез Th2-хелперів забезпечує продукування ІЛ-4, ІЛ-10, ІЛ-13, стимуляцію переважно В-лімфроцитів і гуморальної ланки імунітету [1].

Встановлено, що ІЛ-6 регулює відповідь імунну, гострої фрази запалення і гемопоез. Гіперпродукування цього цитокіну індукує плазмоцитоз, тромбоцитоз, гіпергаммаглобулінемію. Він причетний до патогенезу автоімунних захворювань, дисфункції клітин ендотелію і фріброгенезу [9].

До найважливіших протизапальних інтерлейкінів належить ІЛ-10, який ще й має антицитокінову дію. Він є інгібітором синтезу цитокінів Th1, хемокінів, адгезивних молекул, пригнічує синтез моноцитарно-макрофрагального ФНП- $\alpha$, ІЛ-1, ІЛ-6, ІЛ-12. Цей медіатор підсилює ріст опасистих клітин, В-клітинну проліферацію та секрецію імуноглобулінів. Таким чином, головною фрункцією ІЛ-10 є обмеження та ліквідація запального процесу [10].

Вивчення динаміки активності прозапальних і протизапальних цитокінів дозволяє з'ясувати нові ланки імунопатогенезу борелійної інфекції [1].

Мета дослідження - з'ясувати динаміку прозапальних цитокінів інтерлейкіну $1 \beta$, фрактора некрозу пухлини $\alpha$, інтерлейкіну 6 і протизапального цитокіну інтерлейкіну 10 у сироватці крові пацієнтів з еритемною фрормою Лаймбореліозу залежно від перебігу хвороби.

МЕТОДИ ДОСЛІДЖЕННЯ. СпостерігалИ 83 особи віком від 18 до 70 років з еритемною формою Лайм-бореліозу (ЛБ). Пацієнтів лікували амбулаторно чи стаціонарно в Тернопільському шкірно-венерологічному диспансері протягом 2017-2019 рр. Чоловіків було 35 (42,2 \%), жінок 48 (57,8 \%). Середній вік обстежених становив $(42,65 \pm 13,91)$ року.
Відповідно до сучасної клінічної класифрікації [11], пацієнтів поділили на три групи: 1-шу становили 38 (45,7 \%) осіб з гострим перебігом ЛБ (до 3-х місяців); 2-гу - 32 (38,6 \%) пацієнти 3 підгострим перебігом (від 3-х до 6-ти місяців); 3-тю - 13 (15,7 \%) хворих із хронічним перебігом недуги (понад 6 місяців). Діагноз кільцеподібної мігруючої еритеми встановлювали клінічно на підставі характерних проявів і даних епідеміологічного анамнезу (перебування в ендемічній зоні щодо ЛБ, вказівка на присмоктування кліща), підтверджували виявленням антитіл класів Ig M та Ig G до антигенів комплексу Borrelia burgdorferi sensu lato в сироватці крові під час ІФА. Інших гострих чи хронічних захворювань в обстежених осіб не було.

До контрольної (4-ї) групи ввійшли 30 здорових донорів, які за віком і статтю суттєво не відрізнялись від хворих і заперечували фракт присмоктування кліщів протягом життя. У них на час обстеження не відзначали гострих запальних захворювань чи загострення хронічних, вони не використовували імунотропних препаратів і їм не проводили вакцинації протягом 30-ти днів, які передували обстеженню.

Кров на дослідження забирали через 34 тижні після появи кільцеподібної мігруючої еритеми. Антитіла до антигенів комплексу Borrelia burgdorferi sensu lato (B. burgdorferi sensu stricto, B. Afzelii, B. garinii) в сироватці крові визначали за допомогою ІФА з використанням тест-систем компанії “EuroimmunAG” (Німеччина): класу Ig М - тест-системоюAnti-Borrelia burgdorferi ELISA (Ig M), класу Ig G - Anti-Borrelia plus VIsE ELISA (Ig G). Отримані результати оцінювали як позитивні, проміжні або негативні та інтерпретували згідно з рекомендаціями виробника.

Рівень цитокінів (ФНП- $\alpha$, ІЛ-1 $\beta$, ІЛ-6 та ІЛ-10) у сироватці крові пацієнтів визначали методом ІФА із застосуванням тест-систем виробництва ЗАТ "Вектор-Бест". Ресрерентними значеннями були такі концентрації: для ФНП- - до 6 пг/мл; для ІЛ-1ß - до 11 пг/мл; для ІЛ-6 - до 10 пг/мл; для ІЛ-10 - до 31 пг/мл.

Статистичне опрацювання отриманих результатів проводили 3 використанням методів непараметричної статистики за допомогою комп'ютерних програм Microsoft Office Excel i STATISTICA.

Для кількісних даних 3 неправильним розподілом розраховували медіану (Ме) та нижній $(\mathrm{Lq})$ і верхній (Uq) квартилі, для якісних показників - абсолютну (n) та відносну (\%) кількість.

Усі клінічні та лабораторні дані опрацьовували методами варіаційної статистики з оцінкою достовірності відмінностей показників, які порівнювали. При порівнянні неправильно розподілених ве- 
личин використовували критерій Манна - Уїтні. Результати вважали статистично достовірними при значеннях $p<0,05$.

РЕЗУЛЬТАТИ Й ОБГОВОРЕННЯ. При збиранні анамнестичних даних вдалося з'ясувати, що понад три напади кліщів протягом життя відмітили 36 (43,4 \%) пацієнтів 383 обстежених; два таких епізоди мали 8 (9,6 \%), один - 21 $(25,3 \%)$ респондент. Варто зазначити, що 18 $(21,7$ \%) осіб взагалі не пам'ятали нападів кліщів, проте появу мігруючої еритеми пов'язували 3 відвідуванням лісу, присадибних ділянок або міських парків.

Люди піддавалися нападам кліщів у різних умовах: переважно під час відпочинку в лісосмузі чи лісі - 31 (37,3 \%) випадок, на присадибних ділянках - 19 (22,9 \%) і в парковій зоні - 12 $(14,5$ \%). Слід зазначити, що 21 (25,3 \%) опитана особа не змогла вказати місце нападу кліщів.

Результати дослідження цитокінового статусу у хворих на ЛБ залежно від тривалості перебігу недуги наведено в таблиці. При гострому перебігу іксодового кліщового бореліозу відзначено збільшення в сироватці крові вмісту ІЛ-1及 і ФНП- $\alpha$, а також концентрації іншого прозапального цитокіну ІЛ-6 порівняно з контрольною групою ( $<<0,005)$. Водночас у сироватці крові цих пацієнтів підвищувався вміст протизапального цитокіну ІЛ-10 щодо рівня у здорових осіб $(p<0,005)$.

У пацієнтів з підгострим перебігом ЛБ вміст прозапального цитокіну ІЛ-1 $\beta$ не змінювався, а концентрація ФНП- $а$ була більшою, ніж при гострому перебігу недуги $(p<0,05)$ і в контрольній групі $(p<0,005)$. Рівень іншого прозапального цитокіну ІЛ-6 також був високим, проте дещо нижчим за показник при гострому перебігу іксодового кліщового бореліозу (p>0,05). Рівень протизапального цитокіну ІЛ-10 у цих осіб був меншим, ніж у пацієнтів з гострим перебігом ЛБ ( $>>0,05)$, однак залишався значно більшим за показник у здорових людей ( $<<0,005)$.

В осіб, в яких кільцеподібна мігруюча еритема визначалася через 6 місяців і більше, вміст ІЛ-1 $\beta$ не зростав, рівень іншого прозапального цитокіну ФНП- $\alpha$ був дещо вищим, ніж у пацієнтів 3 гострим перебігом недуги ( $>>0,05)$, і значно більшим порівняно 3 контрольною групою ( $<<0,005)$, а концентрація ІЛ-6 виявилась значно вищою порівняно з особами з підгострим перебігом недуги, проте суттєво не відрізнялась від показника у хворих з гострим перебігом ЛБ. Стосовно концентрації протизапального цитокіну ІЛ-10, то вона була значно вищою порівняно 3 показником в осіб з підгострим перебігом недуги, проте суттєво не відрізнялась від показника в пацієнтів з гострим перебігом ЛБ.

Отже, у хворих на ЛБ зростав вміст у сироватці крові прозапальних цитокінів ФНПта ІЛ-6, а також протизапального цитокіну ІЛ-10. Ступінь збільшення рівня зазначених медіаторів суттєво не залежав від тривалості недуги. Зазначені зміни можна пояснити так: борелії та їх фррагменти, завдяки антигенним властивостям, вмикають механізми специорічного імунного захисту. Макрофраги шкіри у відповідь на активацію бактерійними антигенами і токсинами синтезують прозапальні цитокіни, насамперед ІЛ-1 $\beta$, ІЛ-6, ФНП- $\alpha$. Під час досліджень ми не відзначили суттєвого зростання вмісту ІЛ-1 $\beta$, мабуть, через малу кількість спостережень, а

Таблиця - Вміст інтерлейкінів у сироватці крові хворих з різним перебігом Лайм-бореліозу (Me (Lq; Uq))

\begin{tabular}{|c|c|c|c|c|}
\hline \multirow{3}{*}{ Показник } & \multicolumn{4}{|c|}{ Група хворих } \\
\hline & гострий перебіг & підгострий перебіг & хронічний перебіг & контрольна \\
\hline & 1-ша & 2-га & 3-тя & 4-та \\
\hline ІЛ-1及 & $\begin{array}{c}0,70 \\
(0,00 ; 1,40) \\
p_{1}<0,005\end{array}$ & $\begin{array}{c}0,00 \\
(0,00 ; 0,90)\end{array}$ & $\begin{array}{c}0,00 \\
(0,00 ; 1,00)\end{array}$ & $\begin{array}{c}0,00 \\
(0,00 ; 0,00)\end{array}$ \\
\hline ФНП- $\alpha$ & $\begin{array}{c}0,85 \\
(0,40 ; 1,30) \\
p_{1}<0,005\end{array}$ & $\begin{array}{c}4,80 \\
(4,40 ; 7,10) \\
p_{1}<0,005 \\
p_{2}<0,05\end{array}$ & $\begin{array}{c}4,40 \\
(1,30 ; 7,10) \\
\mathrm{p}_{1}<0,005\end{array}$ & $\begin{array}{c}0,00 \\
(0,00 ; 0,00)\end{array}$ \\
\hline ІЛ-6 & $\begin{array}{c}3,85 \\
(1,25 ; 17,08) \\
p_{1}<0,005 \\
p_{3}<0,05\end{array}$ & $\begin{array}{c}1,50 \\
(0,40 ; 9,60) \\
p_{1}<0,005\end{array}$ & $\begin{array}{c}5,20 \\
(3,40 ; 7,50) \\
p_{1}<0,005 \\
p_{3}<0,05 \\
\end{array}$ & $\begin{array}{c}0,00 \\
(0,00 ; 0,00)\end{array}$ \\
\hline ІЛ-10 & $\begin{array}{c}11,80 \\
(4,50 ; 15,50) \\
p_{1}<0,005 \\
p_{3}<0,05 \\
\end{array}$ & $\begin{array}{c}4,10 \\
(3,10 ; 10,40) \\
p_{1}<0,005\end{array}$ & $\begin{array}{c}17,10 \\
(4,10 ; 19,00) \\
p_{1}<0,005 \\
p_{3}<0,05 \\
\end{array}$ & $\begin{array}{c}0,15 \\
(0,00 ; 1,50)\end{array}$ \\
\hline
\end{tabular}

Примітка. $p_{1}$ - достовірність відхилень $(p<0,005)$ від показників контрольної групи; $p_{2}$ - достовірність відхилень $(p<0,05)$ від показників 1-ї групи; $p_{3}-$ достовірність відхилень $(p<0,05)$ від показників 2-ї групи. 
збільшення концентрації ФНП- $\alpha$ та ІЛ-6 було суттєвим. Відповідь системи цитокінів при ЛБ проявляється посиленим продукуванням ФНП- $\alpha$, який стимулює синтез ІЛ-6 і пригнічує вироблення ІЛ-10, забезпечуючи ранню запальну реакцію, формування клітинного ігуморального імунітенту, що сприяє елімінації борелій та одужанню хворого.

Протизапальний цитокін ІЛ-10, який продукують макрофраги і Th2, знижує активність макрофрагів, синтез цитокінів, пригнічує гіперчутливу відповідь сповільненого типу Th1-клітин, що опосередковує посилення вироблення антитіл класу Ig G $[1,12]$. Високий рівень ІЛ-10 у сироватці крові хворих сприяє створенню передумов для переходу інфекційного процесу в стадію обмеження запалення і швидшому закінченню патологічного процесу. Збільшений вміст протизапального цитокіну ІЛ-10 на тлі високих рівнів прозапальних цитокінів ФНП- $\alpha$ та ІЛ-6, можливо, $€$ показанням до негайного призначення етіотропного лікування або заміни одного антибіотика іншим, щоб запобігти подальшій дисемінації збудника в організмі.

ВИСНОВКИ. 1. Кожний п'ятий пацієнт з кільцеподібною мігруючою еритемою, яка $є$ пато- гномонічною ознакою Лайм-бореліозу, не може вказати на укус кліща в себе.

2. За гострого перебігу кільцеподібної мігруючої еритеми при іксодовому кліщовому бореліозі відзначено достовірне підвищення в сироватці крові рівнів прозапальних ФНП- $\alpha$ та ІЛ-6 і протизапального ІЛ-10, тоді як концентрація іншого прозапального цитокіну ІЛ-1 $\beta$ залишалась у межах норми.

3. Для підгострого і хронічного перебігу еритемної форми ЛБ характерним виявився високий вміст протизапального цитокіну ІЛ-10 на тлі високої концентрації прозапальних цитокінів ФНП- $\alpha$ та ІЛ-6.

4. Збільшений рівень ІЛ-10 у сироватці крові хворих на тлі високого вмісту прозапальних цитокінів може свідчити про відсутність передумов для переходу інфекційного процесу в стадію обмеження запалення.

5. При іксодовому кліщовому бореліозі високий рівень протизапального цитокіну ІЛ-10 на тлі високого вмісту прозапальних цитокінів ФНП- $\alpha$ та ІЛ-6, можливо, є показанням до негайного призначення етіотропного лікування або заміни одного антибіотика іншим для запобігання подальшій дисемінації збудника в організмі.

\section{СПИСОК ЛІТЕРАТУРИ}

1. Шарифулллина Л. Д. Значение иммуноцитокиновых нарушений в патогенезе иксодовых клещевых боррелиозов / Л. Д. Шарифруллина, Р. Т. Мурзабаева // Мед. вестн. Башкортостана. - 2017. - 12, № 1 (67). С. 99-104.

2. Скрипченко Н. В. Современные представления о патогенезе иксодовых клещевых боррелиозов / Н. В. Скрипченко, А. А. Балинова // Журн. инфректологии. - 2012. - 4, № 2. - С. 5-14.

3. Миноранская Н. С. Значение иммунного статуса для прогноза хронизации боррелиозной инфекции I Н. С. Миноранская, А. Н. Усков, П. В. Сарап // Журн. инсректологии. - 2014. - 6, № 1. - С. 35-40.

4. Пролисреративный ответ и продукция иммуноцитокинов мононуклеарными клетками перисрерической крови у больных иксодовым клещевым боррелиозом / Е. Н. Ильинских, А. Г. Семенов, И. Н. Ильинских, Е. А. Чередникова // Иммунопатология, аллергология, инфектология. - 2011. - № 4. - С. 48-53.

5. Сарксян Д. С. Иксодовые клещевые боррелиозы - современное состояние проблемы / Д. С. Сарксян // Инфекционные болезни. - 2015. - № 13 (2). C. 61-67.

6. Ярилин А. А. Иммунология : учебник/А. А. Ярилин. - М. : ГЭОТАР-Медиа, 2010. - 752 с.
7. Naj X. Actin-dependent regulation of Borrelia burgdorferi phagocytosis by macrophages / X. Naj, S. Linder // Curr. Top. Microbiol. Immunol. - 2016. - Oct 16. [Epub ahead of print].

8. Monoinfections caused by borrelia burgdorferi and borrelia burgdorferi / anaplasma phagocytophilum coinfections in forestry workers and farmers / M. TokarskaRodak, A. Pańczuk, M. Kozioł-Montewka [et al.] / Medycyna Pracy. - 2015. - 66 (5). - P. 645-651.

9. Barnes T. C. The many faces of interleukin- 6 : The role of IL-6 in inflammation, vasculopathy, and fibrosis in systemic sclerosis / T. C. Barnes, M. E. Anderson, R. J. Moots // International Journal of Rheumatology. 2011. - 2011. - 6 p. Article ID 721608.

10. Интерлейкин-1, интерлейкин-10 в регуляции воспалительного процесса / С. Н. Серебренникова, И. Ж. Семинский, Н. В. Семенов, Е. В. Гузовская // Сибир. мед. журн. - 2012. - № 8. - С. 5-8.

11. Куляс С. М. Сучасний погляд на особливості специфрічної діагностики, лікування та профрілактики Лайм-бореліозу / С. М. Куляс // Biomedical and Biosocial Anthropology. - 2013. - № 20. - C. 254-250.

12. Lyme borreliosis / G. Stanek, G. P. Wormser, J. Gray, F. Strle // Lancet. - 2012. - 379, No. 9814. P. 461-473. 


\section{REFERENCES}

1. Sharyfullyna, L.D., \& Murzabaeva R.T. (2017). Znachenye immunotsytokinovykh narusheniy $\mathrm{v}$ patogeneze iksodovykh kleshchevykh borreliozov [Importance of immune and cytokine disorders in pathogenesis of ixodic tick-borne borreliosis]. Medytsynskiy vestnyk Bashkortostana - Bashkortostan Medical Journal, 12, 1 (67) [in Russian].

2. Skrypchenko, N.V., \& Balynova, A.A. (2012). Sovremennye predstavleniya o patogeneze iksodovykh kleshchevykh borreliozov [Current knowledge of Lyme disease's pathogenesis]. Zhurnal infektologii - Journal of Infectology, 4, 2, 5-14 [in Russian].

3. Mynoranskaya, N.S., Uskov, A.N., \& Sarap, P.V. (2014). Znachenye immunnogo statusa dlya prognoza khronizatsii borrelioznoy infektsii. Zhurnal infektologii Journal of Infectology, 6 (1), 35-40 [in Russian].

4. Ilyinskikh, E.N., Semenov, A.G., Ilyinskikh, I.N., \& Cherednikova, E.A. (2011). Prolyferatyvnyy otvet produktsiya immunotsytokinov mononuklearnymi kletkami peryferycheskoy krovi u bolnykh iksodovym kleshchevym borreliozom [Proliferative and cytokine responses of peripheral blood mononuclear cells in Lyme-borreliosis patients]. Immunopatologiya, allergologiya, infektologiya Immunopathology, Allergology, Infectology, 4, 48-53 [in Russian].

5. Sarksian, D.S. (2015). Iksodovye kleshchevye borrelyozu - sovremennoe sostoianye problemy [Ixodes tick borreliosis - current state of problem]. Infektsionnyye bolezni - Infectious Diseases, 13 (2), 61-67 [in Russian]
6. Yarilin, A.A. (2010). Immunologiya: uchebnik [Immunology: a textbook]. Moscow: GEOTAR-Media [in Russian].

7. Naj, X., \& Linder, S. Actin-dependent regulation of Borrelia burgdorferi phagocytosis by macrophages. Curr. Top. Microbiol. Immunol., 16 [Epub ahead of print].

8. Tokarska-Rodak, M., Pańczuk, A., Kozioł-Montewka, M., Plewik, D., \& Szepeluk, A. (2015). Monoinfections caused by borrelia burgdorferi and borrelia burgdorferi / anaplasma phagocytophilum co-infections in forestry workers and farmers. Medycyna Pracy, 66 (5), 645-651.

9. Barnes, T.C., Anderson, M.E., \& Moots, R.J. (2011). The many faces of interleukin-6: The role of IL-6 in inflammation, vasculopathy, and fibrosis in systemic sclerosis. International Journal of Rheumatology, 2011.

10. Serebrennikova, S., Seminsky, I., Semenov, N., \& Guzovskaya, E. (2012). Interleykin-1, interleykin-10 v regulyatsii vospalitelnogo protsessa [Interleukin-1, interleukin-10 in regulation of inflammatory process]. Sibirskiy meditsinskiy zhurnal - Siberian Medical Journal, 8, 5-8 [in Russian].

11. Kulias, S.M. (2013). Suchasnyi pohliad na osoblyvosti spetsyfichnoi diahnostyky, likuvannia ta profilaktyky Laim-boreliozu [Current opinion on peculiarities of specific diagnostics, treatment and prevention of lyme borreliosis]. Biomedical and Biosocial Anthropology, 20, 254-250 [in Ukrainian].

12. Stanek, G., Wormser, G.P., Gray, J., \& Strle, F. (2012). Lyme borreliosis. Lancet, 379, 9814, 461-473.

\section{М. И. Шкильна, М. А. Андрейчин, О. Л. Ивахив, Я. И. Йосик, Н. Г. Завиднюк, М. С. Творко, М. М. Корда, И. Н. Клищ ТЕРНОПОЛЬСКИЙ НАЦИОНАЛЬНЫЙ МЕДИЦИНСКИЙ УНИВЕРСИТЕТ ИМЕНИ И. Я. ГОРБАЧЕВСКОГО}

МОЗ УКРАИНЫ

\section{ДИНАМИКА ИНТЕРЛЕЙКИНОВ У БОЛЬНЫХ ЛАЙМ-БОРРЕЛИОЗОМ}

\begin{tabular}{|c|}
\hline 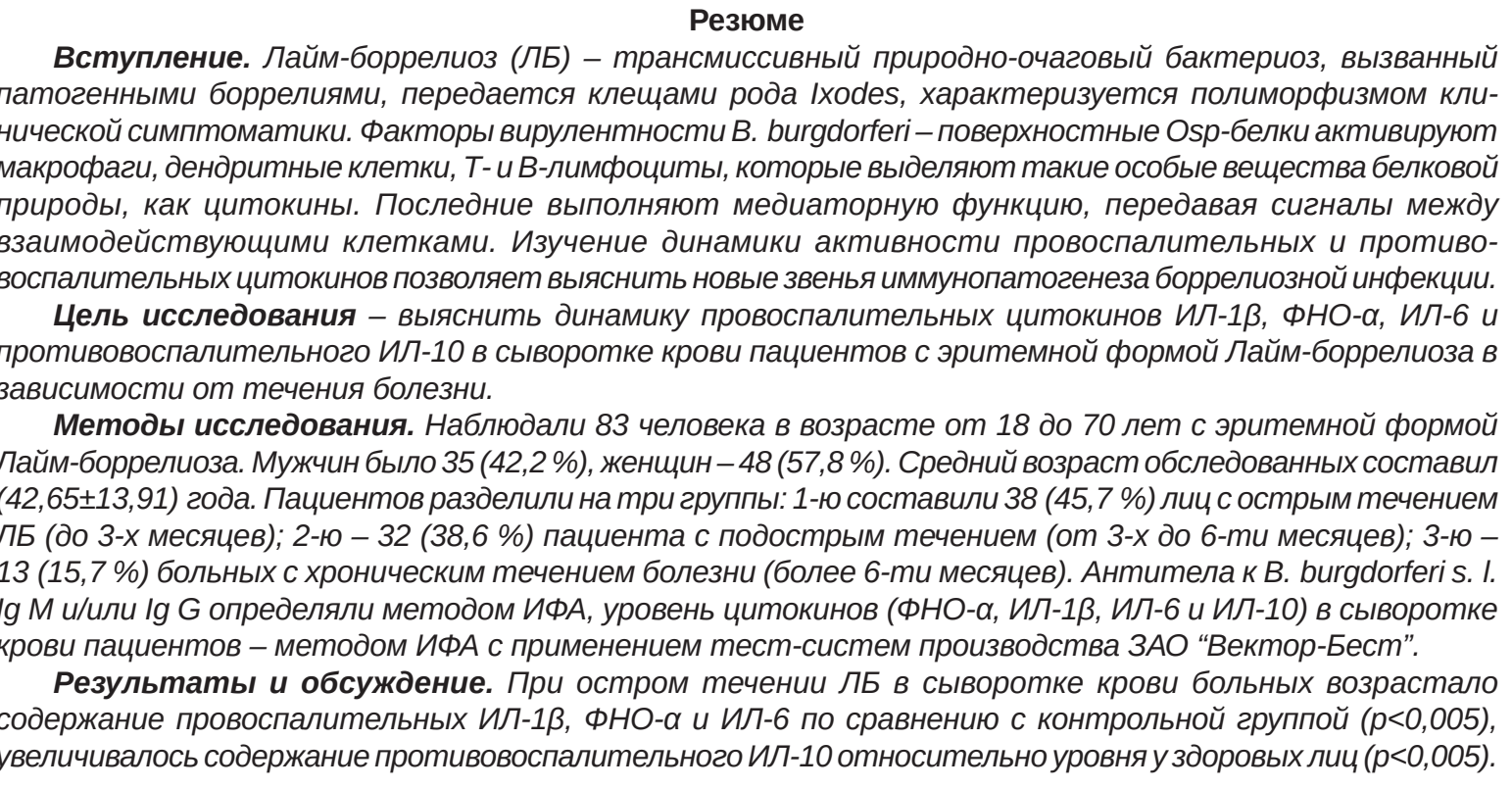 \\
\hline
\end{tabular}


При подостром течении ЛБ содержание провоспалительного ИЛ-1 $\beta$ не менялось, а концентрация ФНО- $\alpha$ была выше, чем при остром течении болезни $(p<0,05)$ и в контрольной группе $(p<0,005)$. Уровень противовоспалительного ИЛ-10 у этих лиц был ниже, чем у пациентов с острым течением ЛБ $(p>0,05)$, однако значительно выше показателя у здоровых людей $(p<0,005)$. У лиц, у которых кольцевидная мигрирующая эритема отмечалась через 6 месяцев и больше, содержание ИЛ-1 $\beta$ не возрастало, уровень ФНО- $\alpha$ был несколько выше, чем у пациентов с острым течением болезни ( $p>0,05)$, а концентрация ИЛ-6 определялась значительно выше в отношении лиц с подострым течением болезни, существенно не отличаясь от показателей у больных с острым ЛБ.

Выводы. Каждый пятый пациент с кольцевидной мигрирующей эритемой не смог указать на укус клеща. Увеличенный уровень ИЛ-10 в сыворотке крови пациентов с ЛБ на фроне высокого содержания провоспалительных цитокинов может свидетельствовать об отсутствии предпосылок для перехода инфекционного процесса в стадию ограничения воспаления данной инфекции и быть, вероятно, показанием к немедленному назначению этиотропного лечения или замены одного антибиотика другим.

КЛЮЧЕВЫЕ СЛОВА: Лайм-боррелиоз; провоспалительные цитокины; противовоспалительный интерлейкин; течение болезни.

M. I. Shkilna, M. A. Andreychyn, O. L. Ivakhiv, I. I. losyk, N. H. Zavidniuk, M. S. Tvorko, M. M. Korda, I. M. Klishch I. HORBACHEVSKY TERNOPIL NATIONAL MEDICAL UNIVERSITY

\title{
INTERLEUKINS DYNAMIC IN PATIENTS WITH LYME BORRELIOSIS
}

\begin{abstract}
Summary
Introduction. Lyme borreliosis (LB) is a transmissible, naturally occurring bacterial disease caused by pathogenic borrelia, transmitted by ticks of the genus Ixodes, characterized by polymorphism of clinical symptoms. Virulence factors of B. burgdorferi surface Osp proteins activate macrophages, dendritic cells, $T$ and $B$ lymphocytes, which secrete specific substances of the protein nature - cytokines. The latter perform a mediating function by transmitting signals between interacting cells. The study of the activity dynamics of pro-inflammatory and anti-inflammatory cytokines allows us to elucidate new links in the immunopathogenesis of borrelia infection.

The aim of the study - to investigate the dynamics of the pro-inflammatory cytokines IL-1 $\beta, T N F-\alpha, I L-6$ and anti-inflammatory IL-10 in the serum of patients with erythematous form of Lyme borreliosis, depending on the disease course.
\end{abstract}

Research Methods. 83 individuals aged from 18 to 70 years with erythematous form of Lyme borreliosis (LB) were observed. There were 35 men (42.2\%), 48 women (57.8\%). The average age of the surveyed was (42.65 \pm 13.91$)$ years. The patients were divided into three groups: group 1 (1) - $38(45.7 \%)$ persons with acute course of LB (up to 3 months); group 2 (2) - 32 patients (38.6\%) with subacute (from 3 to 6 months); group 3 (3) - 13 (15.7\%) patients with chronic course of the disease (more than 6 months). Antibodies to B. burgdorferi s. I. IgM and/or IgG were determined by ELISA. The level of cytokines (TNF- $\alpha, I L-1 \beta, I L-6$ and IL-10) in the serum of patients was determined by ELISA with using test systems produced by CJSC Vector-Best.

Results and Discussion. At the acute course of Lyme-borreliosis in the serum of patients increases the level of pro-inflammatory IL-1 $\beta$, TNF- $\alpha$ and IL-6, compared with the control group $(p<0,005)$, increases the content of anti-inflammatory $I L-10$ relative to the level in healthy individuals $(p<0,005)$. In patients with subacute $L B$, the proinflammatory IL-1 $\beta$ content was unchanged, and TNF- $\alpha$ concentration was higher than at acute course $(p<0.05)$ and in control $(p<0.005)$. The level of anti-inflammatory IL-10 in these individuals was lower than in patients with acute course of LB $(p>0.05)$, but significantly higher than in healthy persons $(p<0.005)$. In individuals with circular erythema migrans noted after 6 months and longer, IL-1 $\beta$ content is not increase, TNF- $\alpha$ levels were slightly higher than those with acute course ( $p>0.05$ ), and IL-6 concentration was significantly higher relative to those with subacute disease, not significantly differs of indices in patients with acute $L B$.

Conclusions. One of five patients with circular erythema migrans was unable to indicate a tick bite. Elevated IL-10 level in the serum of patients with LB on the background of a high content of pro-inflammatory cytokines may indicate that there is no prerequisite for the transition of the infectious process to the stage of limiting inflammation and may be an indication for immediate administration of etiotropic treatment or replacement of one antibiotic to another.

KEY WORDS: Lyme borreliosis; pro-inflammatory cytokines; anti-inflammatory interleukin; course of the disease.

Отримано 16.01.20

Адреса для листування: М. І. Шкільна, Тернопільський національний медичний університет імені І. Я. Горбачевського мОз України, вул. Острозького, 37, Тернопіль, 46006, Україна, e-mail: shkilnami@tdmu.edu.ua. 